J. Clin. Chem. Clin. Biochem.

Vol. 17, 1979, pp. 51-55

\title{
Reduced Lectin Stimulation of Lymphocytes from Magnesium-Deficient Rats
}

\author{
By $T$. Günther
}

Institut für Molekularbiologie und Biochemie and

\section{R. Averdunk}

Institut für Klinische Chemie und Klinische Biochemie Freie Universität Berlin

(Received July 25/September 26, 1978)

Summary: Spleen cells and thymocytes from Mg-deficient rats, fed a Mg-deficient diet for 10-13 weeks, incorporate $\left[{ }^{3} \mathrm{H}\right]$ thymidine at half the rate of normal cells.

The cells from Mg-deficient rats are less stimulated by lectins than those from normal animals.

These effects correspond to the reduced content of $\gamma$-globulins in serum in $\mathrm{Mg}$ deficiency. They are caused by the altered electrolyte content of the $\mathrm{Mg}$-deficient cells.

\section{Verminderte Lectin-Stimulierung der Lymphocyten von Magnesium-Mangel-Ratten}

Zusammenfassung: Lymphocyten aus Milz und Thymus von Ratten, die 10-13 Wochen Mg-arm ernährt wurden, bauen $\left[{ }^{3} \mathrm{H}\right]$ Thymidin nur mit halb so hoher Geschwindigkeit ein wie die Zellen von normal ernährten Ratten.

Die Lymphocyten von Mg-arm ernährten Ratten werden durch Lectine weniger stimuliert als normale Zellen.

Dieses Verhalten erklärt den verminderten Gehalt des Serums an $\gamma$-Globulinen im Mg-Mangel. Es wird durch den veränderten Elektrolytgehalt der Lymphocyten im Mg-Mangel ausgelöst.

\section{Introduction}

Mg-dëficient Yoshida ascites tumor cells (1) or fibroblasts (2) (as well as Mg-deficiēnt animals) exhibit a reduced rate of growth and biosynthesis of DNA, RNA and protein. At the same time, there is an alteration in the intracellular concentrations of $\mathrm{Na}^{+}, \mathrm{K}^{+}, \mathrm{Ca}^{2+}, \mathrm{Mg}^{2+}$ and cAMP (3). Mg deficiency results in increased cell permeability, which leads to a decrease in intracellular $\left[\mathrm{K}^{+}\right]$and $\left[\mathrm{Mg}^{2+}\right]$ and to an increase in intracellular $\left[\mathrm{Na}^{+}\right]$and $\left[\mathrm{Ca}^{2+}\right](1,4)$.

The increased $\left[\mathrm{Na}^{+}\right]$releases stored $\mathrm{Ca}^{2+}$ from mitochondria and produces a further increase in cytosolic $\left[\mathrm{Ca}^{2+}\right]$. The elevated cytosolic $\left[\mathrm{Ca}^{2+}\right]$ leads to a further enhancement of permeability and to a stimulation of adenyl cyclase; this, in turn, causes an increase in intracellular [cAMP], which also increases permeability. The altered concentrations of $\mathrm{Na}^{+}, \mathrm{Ca}^{2+}$, and especially $\mathrm{K}^{+}$may cause the inhibition of DNA-, RNA- and protein biosynthesis (4).
In agreement with the reduced protein biosynthesis, a reduction in immunoglobulins and antibody formation is found during $\mathrm{Mg}$ deficiency (5-8).

A transformation of lymphocytes to lymphoblasts preceeds antibody formation. In this process the membrane permeability is altered, resulting in an increased leakiness of the cell membrane and increased turnover of $\mathrm{K}^{+}$and an enhanced uptake of $\mathrm{Ca}^{2+}$ (for lit. see 1. c. $(9,10))$. These alterations correspond to those in $\mathrm{Mg}$ deficiency. We therefore studied intracellular concentrations of $\mathrm{Na}^{+}, \mathrm{K}^{+}$, the rate of DNA synthesis, and the stimulation of thymus and spleen cells from normal and chronical Mg-deficient rats by lectins.

\section{Methods}

30 male Wistar rats with a body weight of $100 \mathrm{~g}$ were given low-magnesium feed (Altromin C 1035, Mg content

$1.6 \mathrm{mmol} / \mathrm{kg}$ ) and distilled water ad libitum for $10-13$ weeks. 
The control animals were 10 Wistar rats of the same body weight which were fed Altromin ( $\mathrm{Mg}$ content, $83 \mathrm{mmol} / \mathrm{kg}$ ) and tap water $(\mathrm{Mg}$ content of the water, $0.4 \mathrm{mmol} / \mathrm{l})$ ad libitum for the same time period.

The animals were killed under ether anaesthesia.

The number of ery throcy tes and leucocytes, the proportions of granulocy tes and lymphocy tes, the hemoglobin content, the hematocrit values, the $\mathrm{Hb}$ content per erythrocyte and the mean cell volume were determined in a clinical chemical central laboratory by the usual routine methods.

The concentrations of $\mathrm{Na}^{+}$and $\mathrm{K}^{+}$in the serum were measured by flame photometry, and the concentrations of $\mathrm{Ca}^{2+}$ and $\mathrm{Mg}^{2+}$ by atomic absorption spectrometry.

For the determination of the $\mathrm{Na}^{+}$and $\mathrm{K}^{+}$contents of the thymus and spleen, the organs were weighed immediately after their excision and ashed at about $700^{\circ} \mathrm{C}$. The ashes were taken up in $1.0 \mathrm{ml} 0.1 \mathrm{~mol} / 1 \mathrm{HCl}$ and the contents of $\mathrm{Na}^{+}$and $\mathrm{K}^{+}$were determined in a flame photometer (Eppendorf).

For the determination of the rate of DNA synthesis and lectin stimulation, one thymus or spleen was taken from a control animal, or 2-3 from $\mathrm{Mg}$-deficient rats, and homogenized in sterile RPMI medium with $10 \%$ fetal calf serum (Seromed, München). The homogenate was filtered under sterile conditions, and the filtrate was washed $3 \times$ in the same medium by centrifugation at $200 \mathrm{~g}$. The cell concentration was determined by counting in a Neubauer counting chamber.

Bacterial growth in the medium was inhibited by $100 \mu \mathrm{g} / 1$ streptomycin and $10^{5} \mathrm{U} / 1$ penicillin.

The incubation mixtures in stoppered incubation vessels (Falcon) contained

$1.8 \mathrm{ml} \mathrm{RPMI}-10 \%$ calf serum

$0.1 \mathrm{ml}$ cells in $\mathrm{RPMI}-10 \%$ calf serum

$0.1 \mathrm{ml}$ lectin in RPMI - 10\% calf serum

$10 \mu l\left[{ }^{3} \mathrm{H}\right]$ thymidine, radioactivity $37 \mathrm{kBq}=1.0 \mu \mathrm{Ci}(\mathrm{NEN}$

Chemicals, spec. act. $740 \mathrm{TBq} / \mathrm{mol}=20 \mathrm{Ci} / \mathrm{mmol}$ ).

The cell concentration in the incubation mixtures was $2 x$ $10^{6} / \mathrm{mL}$

The lectin concentrations were

Phy tohemagglutinin (Difco) (mg/l): 0, 4, 8, 16, 32, 64

Concanavalin A (Serva, Heidelberg) (mg/1): 0, 4, 8, 16

Lipopolysaccharide (Difco) (mg/1): 0, 30, 40, 50, 60.

The mixtures were gassed with $5 \% \mathrm{CO}_{2}$ containing air and incubated at $37^{\circ} \mathrm{C}$ for $72 \mathrm{~h}$ in an incubation chamber under slow rotation.

To save cells, most experiments were carried out on a micro scale in a microtiter system ( $F$ alcon). The incubation mixtures for this system contained

$0.1 \mathrm{ml}$ cells in RPMI $-10 \%$ calf serum

$0.1 \mathrm{ml}$ lectin in RPMI $-10 \%$ calf serum

$\left.10 \mu \mathrm{l}\right|^{3} \mathrm{H}$ )thymidine with $3.7 \mathrm{kBq}=0.1 \mu \mathrm{Ci}$ (spec. act.

$740 \mathrm{TBq} / \mathrm{mol}=20 \mathrm{Ci} / \mathrm{mmol})$.
The cell and lectin concentrations were the same as in the macro-mix tures. The micro-mixtures were incubated in an incubation chamber gassed with $5 \% \mathrm{CO}_{2}$ containing air.

For experiments with low-Mg RPMI medium, $10 \%$ calf serum and the same substances as in normal RPMI, except for magnesium, were mixed and sterilized by filtration. $(\mathrm{Mg}$ content of the low-Mg RPMI medium $=0.1 \mathrm{mmol} / \mathrm{l}$ ).

At the end of the experiment, the cells were centrifuged off for $10 \mathrm{~min}$ at $800 \mathrm{~g}$ and washed $3 \times$ in cooled $0.15 \mathrm{~mol} / 1$ $\mathrm{NaCl}$. The cell sediment from the $2 \mathrm{ml}$ incubation mixtures was taken up in $2 \mathrm{ml} 0.1 \mathrm{~mol} / \mathrm{l} \mathrm{NaOH}$, and the sediment from the $0.2 \mathrm{ml}$ mixtures in $0.2 \mathrm{ml} 0.1 \mathrm{~mol} / 1 \mathrm{NaOH}$. The radioactivity of a $0.1-\mathrm{ml}$ aliquot was measured in $10 \mathrm{ml}$ dioxan scintillation mixture in a Tricarb (Packard) counter.

The DNA was determined according to Burton (11), and the protein according to Lowry et al. (12).

\section{Results}

\section{Electrolyte content in serum, spleen and thymus}

During the period of $\mathrm{Mg}$ deprivation, the changes typical for $\mathrm{Mg}$ deficiency occured. The $\mathrm{Mg}$ concentration in the serum decreased to $0.32 \pm 0.05 \mathrm{mmol} / 1$ $(\bar{x} \pm$ SEM, $n=6)$, compared to a control value of $0.98 \pm 0.14 \mathrm{mmol} / \mathrm{l}(\overline{\mathrm{X}} \pm \mathrm{SEM}, \mathrm{n}=6)$. The $\mathrm{Na}^{+}$and $\mathrm{K}^{+}$ concentrations in the serum did not change, whereas the $\mathrm{Ca}^{2+}$ concentration was increased by $4 \%$. In the thymus and spleen of the magnesium-deficient rats, the $\mathrm{Na}^{+}$content rose about $45 \%$, and the $\mathrm{K}^{+}$content decreased about $67 \%$.

\section{Blood count}

The various parameters of the blood count were determined in order to facilitate comparison with other experiments (tab. 1). The erythrocyte count, and thus the hematocrit values, decreased during the experiment. This corresponds to the previously observed changes in chronic $\mathrm{Mg}$ deficiency $(13,14,15)$. The loss of $\mathrm{Hb}$ was somewhat less severe than the decrease in erythrocyte count, so that the $\mathrm{Hb}$ content per erythrocyte rose slightly. This effect does not result from a smaller cell volume of the Mg-deficient erythrocytes. They were . found to be somewhat swollen (tab. 1). The number of leucocytes increased by $52 \%$; granulocytes and lymphocytes were equally affected.

Tab. 1. Blood count from 5 normal and $7 \mathrm{Mg}$-deficient rats. Mean \pm S. E. M. $\mathrm{MCH}=$ mean cell hemoglobin, $\mathrm{MCV}=$ mean cell volume

\begin{tabular}{llllllllll}
\hline & $\begin{array}{l}\text { Ery thro- } \\
\text { cytes } \\
{\left[10^{12} / 1\right]}\end{array}$ & $\mathrm{Hb}$ & Hematocrit & $\mathrm{MCH}$ & $\mathrm{MCV}$ & $\begin{array}{l}\text { Leuko- } \\
\text { cytes }\end{array}$ & $\begin{array}{l}\text { Granulo- } \\
\text { cyte } \\
\text { fraction }\end{array}$ & $\begin{array}{l}\text { Lymphocyte } \\
\text { fraction }\end{array}$ \\
\hline $\begin{array}{l}\text { normal } \\
\text { rats } \\
(\mathrm{n}=5)\end{array}$ & $7.15 \pm 0.19^{\circ}$ & $14.86 \pm 0.28$ & $0.376 \pm 0.011$ & $20.5 \pm 0.5$ & $0.52 \pm 0.01$ & $6.46 \pm 0.18$ & $0.085 \pm 0.006$ & $0.882 \pm 0.016$ \\
$\begin{array}{l}\mathrm{Mg} \\
\text { deficient } \\
\text { rats } \\
(\mathrm{n}=7)\end{array}$ & $5.80 \pm 0.21$ & $13.70 \pm 0.21$ & $0.340 \pm 0.005$ & $22.3 \pm 0.5$ & $0.57 \pm 0.01$ & $9.82 \pm 0.48$ & $0.090 \pm 0.006$ & $0.87 .0 \pm 0.017$ \\
\hline
\end{tabular}




\section{Immunoglobulins}

In the present experiments, we found a decrease in the serum proteins, particularly the $\boldsymbol{\gamma}$-globulins (not shown), in agreement with earlier results (5-8).

\section{Lymphocyte stimulation}

In the process of antibody formation, lymphocytes are transformed to lymphoblasts, and these multiply clonally. The blast transformation can be experimentally induced by stimulation with lectins.

Table 2 shows that the rate of incorporation of $\left[{ }^{3} \mathrm{H}\right]$ thymidine into spleen and thymus cells of chronically $\mathrm{Mg}$-deficient rats is reduced to half the control value. The same difference between normal and $\mathrm{Mg}$ deficient cells is found when the cells are incubated in a low-Mg RPMI-medium with $10 \%$ calf serum. In this medium, the rates of incorporation were only $20 \%$ lower than in normal medium, in both $\mathrm{Mg}$-deficient and normal cells.

The stimulation of spleen and thymus cells from normal rats by phytohemagglutinin, lipopolysaccharide or concanavalin $\mathrm{A}$ is 1.5 times higher than the stimulation of cells from Mg-deficient animals. In low-Mg RPMI medium, the stimulation by phytohemagglutinin, lipopolysaccharide or concanavalin A of normal and Mg-deficient spleen and thymus cells is in each case about $20 \%$ lower than in normal RPMI medium. The optimal lectin concentrations for cells from normal and $\mathrm{Mg}$-deficient animals were not significantly different.

After the addition of lectin and subsequent incubation, some of the cells clump and die. After 2 days, all the surviving lymphocytes proliferate (16).

For a quantitative evaluation of the above results, it is therefore necessary to know whether the cells from $\mathrm{Mg}$-deficient animals are destroyed at a higher rate by lectins, or whether they proliferate less vigorously. In some of the experiments, therefore, we determined the DNA and protein contents of the cells after the three-day incubation with lectins. We found that the protein and DNA contents of the cultures of spleen and thymus cells from normal rats were not significantly changed by the lectins and the incubation in low-Mg RPMI medium. With the cell cultures from Mg-deficient rats we again found the same DNA and protein contents. with and without lectins, and in both media. From this one can conclude that the cells from $\mathrm{Mg}$-deprived animals are not significantly more sensitive to lectins than normal cells. However, the protein and DNA contents of cultures of spleen and thymus cells from Mg-deficient animals were 25\% lower than the controls after 3 days incubation, al though the number of cells at the beginning of the experiment was the same. This indicates that the cells from $\mathrm{Mg}$-deficient rats have a lower proliferation rate.

Tab. 2. Effects of lectins on the incorporation of $\left[{ }^{3} \mathrm{H}\right]$ thymidine in spleen cells and thymocy tes from normal and $\mathrm{Mg}$-deficient rats in normal and low-Mg medium. The lectin concentrations at which maximal stimulation occurred were $16 \mathrm{mg} / \mathrm{l}$ for phy tohemagglutinin, $50 \mathrm{mg} / 1$ for lipopolysaccharide and $8 \mathrm{mg} / 1$ for concanavalin A. Mean $\pm \mathrm{S}$. E. M. from 7 different experiments each.

Rate of $\left[{ }^{3} \mathrm{H}\right]$ thymidine incorporation

Normạ medium

unstimulated

[counts/min . $10^{6}$ cells]

\section{Phyto-}

hemagglutinin

stimulated

unstimulated
Lipopolysaccharide

stimulated

unstimulated
Mg-deficient medium

unstimulated Phyto- Lipo-

[counts/min - hemagglutinin polysaccharide

$10^{6}$ cells] stimulated stimulated

unstimulated $\quad$ unstimulated

\begin{tabular}{|c|c|c|c|c|c|c|}
\hline \multicolumn{7}{|l|}{ Spileen } \\
\hline $\begin{array}{l}\text { Normal rats } \\
(n=7)\end{array}$ & $536 \pm 86$ & $3 . \overline{7} 4 \pm 0.28$ & $1.87 \pm 0.24$ & $435 \pm 75$ & $3.08 \pm 0.28$ & $1.68 \pm 0.23$ \\
\hline \multirow[t]{2}{*}{$\begin{array}{l}\text { Mg-deficient } \\
\text { rats }(n \equiv 7)\end{array}$} & $294 \pm 36$ & $2.63 \pm 0.26$ & $1.22 \pm 0.17$ & $237 \pm 50$ & $2.00 \pm 0.18$ & $1.18 \pm 0.10$ \\
\hline & $\begin{array}{l}\text { unstimulated } \\
\text { [counts/min } \\
10^{6} \text { cells] }\end{array}$ & $\begin{array}{l}\text { Phyto- } \\
\text { hemagglutinin } \\
\text { stimulated } \\
\text { unstimulated }\end{array}$ & $\begin{array}{l}\text { Concanavalin A } \\
\text { stimulated } \\
\text { unstimulated }\end{array}$ & $\begin{array}{l}\text { unstimulated } \\
\text { [counts/min } \\
10^{6} \mathrm{cells} \text { ] }\end{array}$ & $\begin{array}{l}\text { Phyto- } \\
\text { hemagglutinin } \\
\text { stimulated } \\
\text { unstimulated }\end{array}$ & $\begin{array}{l}\text { Concanavalin A } \\
\frac{\text { stimulated }}{\text { unstimulated }}\end{array}$ \\
\hline \multicolumn{7}{|l|}{ Thymus } \\
\hline $\begin{array}{l}\text { Normal rats } \\
(n=7)\end{array}$ & $505 \pm 125$ & $2.23 \pm 0.18$ & $19.6 \pm 2.0$ & $360 \pm 72$ & $2.00 \pm 0.13$ & $16.0 \pm 1.0$ \\
\hline $\begin{array}{l}\text { Mg-deficient } \\
\text { rats }(\mathrm{n}=7)\end{array}$ & $220 \pm 61$ & $1.96 \pm 0.32$ & $12.0 \pm 0.5$ & $177 \pm 30$ & $1.62 \pm 0.29$ & $9.5 \pm 0.6$ \\
\hline
\end{tabular}




\section{Discussion}

Typical symptoms of chronic $\mathrm{Mg}$ deficiency appeared in our experimental animals during the 10 to 13 weeks of $\mathrm{Mg}$-deficient diet. These included a decrease in the $\mathrm{Mg}$ concentration in the serum, mild anemia, leucocytosis and a decrease in the serum proteins, especially the $\boldsymbol{\gamma}$-globulins. The leucocytosis was less pronounced than that found by other workers (15), who reported a 2.5-fold increase.

In one animal, an infiltratively growing lymphocytic thymoma had formed after 90 days. This corresponds to the results of others (14), who found a rate of such tumors between 5 and $20 \%$, depending on the strain.

The most significant result was the reduced incorporation of thymidine in the spleen and thymus cells of $\mathrm{Mg}$-deficient animals and the reduced responsiveness of these cells to lectins.

The rates of stimulation in the control cells, four-fold for phytohemagglutinin and 19-fold for concanavalin A, are relatively low compared to those in peripheral lymphocytes. One reason for this is the high cell density of $2 \cdot 10^{6} / \mathrm{ml}$ used in these experiments; with $10^{5} / \mathrm{ml}$ the stimulation rates are ten times higher (16). Furthermore, in the thymus $10-20 \%$ of the cells are mitotically active, in contrast to the peripheral lymphocytes (18).

The spleen and thymus cells from Mg-deficient rats incorporated thymidine at half the control rates, but their DNA and protein contents were only about $25 \%$ lower. It follows that the spleen and thymus cells of Mg-deficient animals have a lower rate of DNA synthesis or proliferation than normal cells. A related phenomenon is the lower responsiveness of the $\mathrm{Mg}$-deficient spleen and thymus cells to lectins.

After incubation in low-Mg RPMI medium, the DNA synthesis rates and the responsiveness of both control and Mg-deficient cells are about 20\% lower. It is unlikely that this effect results from a reduced binding of lectins to their receptors at the cell membrane in the low-Mg medium, because there was no alteration in the optimal lectin concentrations in the low-Mg medium. The reduced responsiveness in cells from $\mathrm{Mg}$-deprived animals and in Mg-poor RPMI medium explains the decrease in the $\gamma$-globulin fraction in the serum and the reduced immunizability of $\mathrm{Mg}$-deprived rats (15).

The cause of this behaviour must lie in changes in the electrolyte and cell metabolism of Mg-deficient cells. In these cells, an increased permeability causes a drop in the $\mathrm{K}^{+}$concentration and a rise in the intracellulai concentrations of $\mathrm{Na}^{+}, \mathrm{Ca}^{2+}$ and cAMP, and an inhibition of the synthesis of protein and DNA $(1,3,4)$. We also observed these changes in the $\mathrm{Na}^{+}$and $\mathrm{K}^{+}$concentrations in the spleen and thymus cells of the $\mathrm{Mg}$-deficient rats.

The permeability of the cell membrane is also increased during lectin stimulation $(9,10)$. The effects of $\mathrm{Mg}$ deficiency and lectins on the membrane may be additive. If the changes in the concentrations of ions and substrates caused by increased permeability are not compensated by increased active transport rates, the intracellular $\mathrm{K}^{+}$concentration decreases, among other things. If this decrease exceeds $10-20 \%$ of the normal $\mathrm{K}^{+}$concentration, DNA and protein synthesis decrease in parallel to the $\mathrm{K}^{+}$concentration (19).

The decreased responsiveness of $\mathrm{Mg}$-deficient lymphocytes to lectins corresponds to the reduction in the number of plaque-forming cells after i. v. injection of sheep erythrocytes into $\mathrm{Mg}$-deprived animals (8), and explains the reduced antibody synthesis in $\mathrm{Mg}$ deficiency. The cause may be the reduced rate of protein synthesis due to the decrease in intracellular $\mathrm{K}^{+}$concentration. Due to the complex mechanism of the immune response, the details of which are still not completely clear, other effects may interfere in $\mathrm{Mg}$ deficiency. The $\mathrm{Mg}$ content decreases and the intracellular concentrations of CAMP and $\mathrm{Ca}$, and probably also of $\mathrm{Ca}^{2+}$ ions, increase. The increase in the intracellular $\mathrm{Ca}^{2+}$ concentration plays a decisive role in the immune response. The $\mathrm{Ca}$ ionophore A 23187, which increases the intracellular $\left[\mathrm{Ca}^{2+}\right]$, is by itself mitogenic. An increase in the intracellular $\mathrm{Ca}^{2+}$ concentration is also involved in the effects of other lectins. It may represent a common member in the reaction chain because the effects of suboptimal concentrations of A 23187 and phytohemagglutinin are additive (20). Nevertheless, the DNA synthesis and responsiveness of $\mathrm{Mg}$-deficient lymphocytes to lectins were reduced.

The reason for this behaviour may be the severe reduction in the intracellular $\mathrm{K}^{+}$concentration in $\mathrm{Mg}$ deficiency which decreases the rate of protein synthesis. Apparently lymphocyte stimulation requires both an increase in the $\mathrm{Ca}^{2+}$ concentration and a sufficient $\mathrm{K}^{+}$concentration. This might also be an explanation for the fact that the less specific $\mathrm{Ca}$ ionophore X $537 \mathrm{~A}$ is not mitogenic (9). It apparently reduces the intracellular $\mathrm{K}^{+}$concentration too far. The inhibition of lymphocyte stimulation by ouabain, the specific inhibitor of $\mathrm{Na}^{+}-\mathrm{K}^{+}$transport, can be explained in the same way (9).

Since the development of leukocytosis and thymomas is associated with a higher synthesis rate in these cells, another, presently unknown mechanism must be responsible for their formation. 


\section{References}

1. Günther, T. \& Averdunk, R. (1970), Z. Klin. Chem. Klin. Biochem. 8, 621-625.

2. Sanui, H. \& Rubin, H. (1977), J. Cell. Physiol. 92, 23-32.

3. Averdunk, R., Ostapovicz, B. \& Günther, T. (1975), Z. Klin. Chem. Klin. Biochem. 13, 361-366.

4. Günther, T., Averdunk, R. \& Ising, H. in: M. Cantin (ed.) Proc. 2. Intern. Symposium on Magnesium, Spectrum Publ. Inc. Holliswood (in press).

5. Schmalbeck, J., Willems, W. R., Dorn, F. \& Günther, T. (1972), Z. Klin. Chem. Klin. Biochem. 10, 270-274.

6. Alcock, N. W. \& Shils, M. E. (1974), Proc. Soc. Exp. Biol. Med. 145, 855-858.

7. Rayssiguier, Y., Larvor, P., Augusti, Y. \& Durlach, J. (1977), Ann. Biol. Anim. Biochim. Biophys. 17, 147-152.

8. Elin, R. J. (1975), Proc. Soc. Exp. Biol. Med. 148, 620-624.

9. Kaplan, J. G. (1977), in Regulatory mechanisms in lymphocyte activation (Lucas, D. O., ed.). Acad. Press. Inc., p. 51-75.

10. Segel, G. B. \& Lichtman, M. A. (1978), Exp. Cell. Res. $112,95-102$.

11. Burton, K. (1956), Biochem. J. 62, 315-323.
12. Lowry, O. H., Rosebrough, N., Farr, A. L. \& Randall, R. J. (1951), J. Biol. Chem. 193, 265-275.

13. Piomelli, S., Jansen, V. \& Dancis, J. (1973), Blood 41, 451-459.

14. Elin, R. J., Armstrong, W. D. \& Singer, L. (1971), Proc. Soc. Exp. Biol. Med. 137, 635-640.

15. Battifora, H. (1971), in 1. Internat. Symposion über $\mathrm{Mg}$ Mangel in der menschlichen Pathologie, (Durlach, J., ed.) Vittel, p. 501-516.

16. Bernheim, J. L. \& Mendelsohn, J. (1977), in Regulatory mechanisms in Lymphocy te activation (Lucas, D. O., ed.) Acad. Press. Inc., p. 479-505.

17. Bois, P. (1964), Nature 204, 1316.

18. Whitfield, J. F., Perris, A. D. \& Rixon, R. H. (1969), J. Cell. Physiol. 74, 1-8.

19. Ledbetter, M. L. S. \& Lubin, M. (1977), Exp. Cell Res. $105,223-236$.

20. Crumpton, M. J., Perles, B. \& Auger, J. (1977), Exp. Cell. Res. tional Cell Biology (Brinkley, B. R. \& Porter, R. K., eds.) Rockefeller Univers. Press, p. 119-127.

Prof. Dr. Th. Günther Institut für Molekularbiologie und Biochemie der Freien Universität Berlin Arnimallee 22

D-1000 Berlin 33 